


TÜRK POPÜLER MÜZIK TARIHINDE BARIŞ MANÇO'NUN YERI VE ÖNEMi (1960-1980)

The Place and Importance of Barış Manço ln The Hıstory of Turkısh Popular Music (1960-1980)

\title{
Göktürk ERDOĞAN
}

Dr. Öğr. Ülyesi, Munzur Üniversitesi, Güzel Sanatlar Fakültesi, Müzik Bilimleri Ana Sanat Dalı erdogangokturk77@gmail.com

(iD) https://orcid.org/ 0000-0001-8174-6979

Ağrı ibrahim Çeçen Üniversitesi Sosyal Bilimler Enstitüsü Dergisi-Journal of Ağrı ibrahim Çeçen University Social Sciences Institute AiCUSBED 5/1 Nisan/April 2019 / Ağrı

\section{ISSN: $\quad 2149-3006$}

e-1SSN: 2149-4053

\begin{tabular}{|l|l|}
\hline Makale Türü-Article Types : & Araştırma Makalesi \\
\hline Geliş Tarihi-Received Date $:$ & $20.02 .2019-$ \\
\hline Kabul Tarihi-Accepted Date $:$ & $\mathbf{2 4 . 0 3 . 2 0 1 9}$ \\
\hline Sayfa-Pages $:$ 105-117 & \\
\hline
\end{tabular}

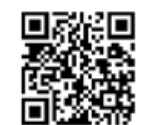

http://dergipark.gov.tr/aicusbed

This article was checked by

$\checkmark$ iThenticate 



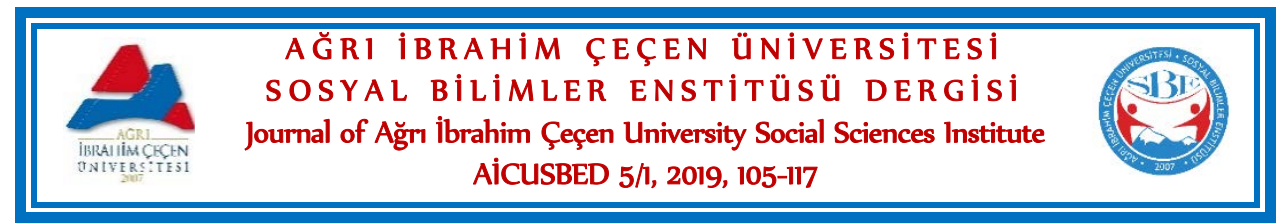

\section{TÜRK POPÜLER MÜZIK TARIHINDE BARIŞ MANÇO'NUN YERI VE ÖNEMi} (1960-1980)

The Place and Importance of Barış Manço In The Hıstory of Turkısh Popular Music (1960-1980)

Öz

Dünyada XX. yüzyılın ikinci yarısından itibaren iletişim ve teknolojinin gelişmesiyle birlikte popüler müzikler ön plana çıkmışır. Türk pop müziği adına yapılan çalışmalar ise aranjman müzik ile başlamış ve bu süreçte geleneksel motifleri kendi müziğine aktarmış olan Barış Manço, bugün adına Anadolu pop/rock denilen türün gelişmesinde büyük pay sahibi olmuştur. Aranjman müzik olarak ilk Türkçe pop denemelerinin yapıldı̆̆ $1960^{\prime}$ ların başında, Elvis Presley, The Beatles gibi dünyaca ünlü şarkıcı ve grupların yaptığı şarkılar, Türkiye'de yaşayan çeşitli grupların sahnesinde çalınmaya ve söylenmeye başlanmıştır. 1960'lı yıllarda aranjman müzik olarak adlandırılan müzikler, $1970^{\prime}$ li yıllarla birlikte daha özgün ve geleneksel bir çizgiye dönüşerek "Anadolu pop" akımının doğmasına kapı aralamıştır. Bu çalışmada 1960 ve 1980 yılları arasında Türk popüler müziğinin gelişim süreçleri çeşitli olgularla birlikte incelenerek Barış Manço'nun popüler müzik içerisindeki yeri ve önemi ortaya konmaya çalışılmıştır.

Anahtar Kelimeler: Barış Manço, Anadolu Pop, Aranjman müzik

\section{Abstract}

With the development of communication and technology in the world from the second half of $20^{\text {th }}$ century popular music has come into prominence. The works conducted on behalf of Turkish pop music have started with the arrangement music and Barış Manço who transferred traditional motifs into his own music in this process, has a major role in the development of the genre called as Anatolian pop/rock today. At the beginning of 1960's when the first Turkish pop practices were carried out as arrangement music, the songs composed by famous groups and singers such as Elvis Presley and The Beatles were started to be played and sung in the stages of various groups that live in Turkey. Music called as arrangement music in 1960's, pave the way for the birth of "Anatolian pop" movement by turning into a more original and traditional pattern in 1970's. In this study, it has been attempted to put forward the place and importance of Barış Manço in popular music by examining the development process of Turkish popular music between the years of 1960 and 1980 along with various facts.

Keywords: Barış Manço, Anatolian Pop, Arrangement music. 
Giriş

Tanzimat'la başlayan (1839) ve Cumhuriyetin ilk yılları ile birlikte pek çok alanda iyiden iyiye hız kazanan modernleşme çabaları, milliyetçilik akımları ve merkezi otoriteye dayalı ulus-devlet yapılanmasının harekete geçirdiği toplumsal dinamikler, Türkiye'de müzik alanında da kendisini göstermiştir. Dilde yapılan inkılaplar, bir süre sonra halk türkülerini derleme çalışmaları ile devam etmiş ve milli kültürü yeniden inşa etme adına kültür ve sanat odaklı çalışmalara yönelimi de hızlandırmıştır. Garp ve Şark müziği tartışmaları etrafında milli bir kimlik arayışına giren Türkiye, batıdaki çoksesli müziği modernleşmenin (adeta) bir zorunluluğu olarak görerek bu alana yönelmiş ve tıpkı Rusların yaptı̆̆ı gibi adına Türk Beşleri denilen beş kişilik bir ekip (1920 ve 1930 yılları arasında farklı yıllarda) Avrupa'ya Batı polifonik müziğinin besteleme tekniklerini öğrenmek üzere devlet bursuyla gönderilmiştir. Sanat müziği ise Osmanlı saray kültürünü temsil ettiği, halk müziğine nazaran daha dar bir çevrede kaldığı, gelişmeye müsait olmadığı ve Türkiye'nin gerçek müziğini temsil edemeyeceği gibi gerekçelerle rağbet görmemiştir. Aynı şekilde tekke ve zaviyelerin kapatılması ile birlikte dini müzik, seküler bir kimlik arayışında olan genç Türkiye adına modernleşmenin önündeki en büyük engel olarak düşünülmüştür. Hiç şüphesiz dönemin mevcut siyasi ve toplumsal koşulları göz önüne alındığında müzik kültürü adına atılan bazı adımların anlaşılabilir olduğu, bazılarında ise kantarın topuzunun kaçtı̆̆ı söylenebilir.

Türkiye'de popüler müziğin tarihi ise $1920^{\prime} l_{1}$ yıllarda Cumhuriyetin hemen öncesi dönemde kantolarla başladığı söylenebilir. Kahyaoğlu'na göre (2010: 226) kantoların tutulmasının sebebi bu türün hem Osmanlı geleneksel müziğine, hem de Batı popüler müziğine yakın olmasından ve kendine özgü bir anlayışla eğlenceye ve kadın sahne gösterisine dayalı olmasından kaynaklanmaktadır. Bu müzik türünün 1950'li yılların başına kadar da popülerliğini koruduğu bilinmektedir. Kantolardan sonraki dönemde Türkiye'de popüler müziğin tarihi özellikle 1950'li yılların sonu ile 1960'lı yılların başına denk düştüğü ve o dönem aranjman müzik olarak adlandırılan müzik tarzı ile başladığı bilinmektedir,. Yabancı parçaların müziklerine Türkçe sözler yazıldığı 1960'larda, henüz kendi kimliğini ve yönünü bulamamış olan Türk popu, siyasal, ekonomik ve kültürel açıdan da yönünü batıya çevirmiştir. Il. Dünya savaşı sonrası dünyadaki mevcut toplumsal ve ekonomik koşullar giderek güç kazanan Amerika'yı, askeri olduğu kadar teknolojik ve kültürel anlamda da güçlendirmiştir. 1950 yılı ile birlikte çok partili hayata geçen ve demokrasi adına önemli bir adım atan genç Türkiye Cumhuriyeti ise, 1952 yılında NATO'ya üye olmuş, 1954 yılında Kore'ye asker göndermiş ve kültürel anlamda olduğu kadar siyasal ve askeri anlamda da Batı ile birlikte hareket edeceğini ve yüzünü Batı́ya döneceğinin somut adımlarını atmıştır. 27 Mayıs 1960 yılında ise Menderes hükümetine karşı askeri bir darbe yapılarak ülkedeki tansiyon yükselmiştir. 1961 yılında yeni anayasa düzenlemesi ile bazı değişiklikler söz konusu olmuştur. Bununla birlikte 27 Mayıs 1960'ı takip eden dönemde güçlenen halkçılık anlayışı edebiyatımız açısından köy gerçeğini de gündeme getirmiştir. Mahmut Makal (“Bizim Köy” 1950, “Köylümden 1952, Köye

http://dergipark.gov.tr/aicusbed 5/1 Nisan / April 2019 
Gidenler 1959), Yaşar Kemal ("Yanan Ormanlarda 50 Gün” 1955, “Çukurova Yana Yana” 1955), Fakir Baykurt ("Yılanların Öcü” 1954, “Onuncu Köy” 1961) gibi yazarların romanları çok okunurken, Ahmet Arif, Hasan Hüseyin gibi Anadolu kökenli şairlerin şiirleri bu dönemde toplumun dikkatini çekmeye başlarmıştır (Cambazoğlu, 2009: 25).

Tüm bu tartışmaların ötesinde Anadolu'da ise halk müziği o dönem için hala çalınıp söylenmekte ve yaşatılmaktadır. Bir tarım toplumu olarak Türkiye'de halk müzikleri adına yapılacak olan derleme çalışmaları ise müzik adına gerçekleştirilmesi planlanan bir kalkınmanın başlangıç noktasını oluşturacağı düşünülmüştür. Nitekim 1930'lu yılların ortalarında Milli Eğitim Bakanlı̆̆ı tarafından ülkeye davet edilen yabancı bestecilerin (Pual Hindemit-1935, Bela Bartok-1936) önerileri doğrultusunda Türk müziği adına yapılacak çok sesli bir çalışmanın mutlaka Anadolu halk ezgileri ile başlatılması gerektiği de ifade edilmiştir. Ancak batı tarzı yapılan ve radyoda yayınlanan çok sesli düzenlemeler, toplumda rağbet görmemiş ve Cumhuriyet dönemi müzik politikaları 1960'lı yıllara gelindiğinde tam olarak istenilen seviyeye ulaştırılamamıştır. Bu döneme asıl damgasını vuracak olan ise Avrupa ve Amerika'da kitleleri peşinden sürükleyen ve özellikle kentlerde gençler tarafindan dinlenen popüler müziklerdir. 11. Dünya savaşı sonrası Avrupa'da yaşanan toplumsal travmalar, gençlerin savaş karşıtı gösterilerine sebep olmuş ve adına "hippy" denen genç kitle, dünya siyasetinin savaş politikasına karşı bir tepki göstererek müziği bir kaçış alanı olarak görmüştür. "Savaşma seviş” sloganı da 1960'lı yıllarda "hippy” kuşağının yaşam felsefesi olarak sloganlaşmıştır. Sanayi devrimi yapmış toplumlarda yeni popüler müzikler, yeni tüketim halkasının, ideolojisinin kopmaz parçası olmaya başlamış ve 1950'lerden sonra müzik endüstrisi, uluslararası ölçekte dünyada ciddi bir pazar payına sahip olmuştur (Kahyaoğlu, 2010: 299). 1950'lili yılların sonlarına doğru iyice şekillenen popüler müzik endüstrisi, Elvis Presley, The Beadles, Pink Floyth gibi dünyaca ünlü grup ve şarkıcılarla birlikte 1960'lı yıllara damgasını vurarak, 1960 sonrası popüler müzik dünyasını şekillendiren öncü isimler olmuşlardır. Türkiye ise bu süreçte aranjman müzik ile tanışmış ve dünyada giderek genişleyen müzik endüstrisine karşı kendisine yön bulmaya çalışmıştır.

\section{Aranjmandan Yerel Müziklere Doğru}

Aranjman müzik (diğer adıyla Türkçe sözlü hafif müzik) olarak ilk Türkçe pop denemelerinin yapıldığı 1960'ların başında, Elvis Presley, The Beatles gibi dünyaca ünlü şarkıcı ve grupların yaptığı şarkılar çeşitli Türk gruplarının sahnesinde çalınmaya ve söylenmeye başlamıştır. Büyük kentlerde yaşayan gençlerin dinlediği bu şarkılar zamanla aranjman müziğin ağırlık kazanmasına ve dönemin hakim müzik türlerinin ve danslarının (Blues, Ça-ça, Twist) Türkiye'de de yaygınlaşmasını sağlamıştır. ilk aranjman müzik olarak ise Febri Ebcioğlu'nun sözlerini yazdığı ve ilhami Gencer'in seslendirdiği “Bak Bir Varmış Bir yokmuş” adlı parça, Türk popüler müzik tarihinde yerini almaktadır (Erdoğan, 2018: 26). 1960'lı yılların başında aranjman müzik modası giderek yaygınlaşırken, söz ve müziği Türkçe olan eserler de gündeme gelmeye başlamıştır. Halk müziğinin geleneksel ezgilerinden ve

http://dergipark.gov.tr/aicusbed 5/1 Nisan / April 2019 
motiflerinden yola çıkılarak oluşturulan şarkılarda aranjman müziğine karşı "yerli" müzik tekrar gündeme gelmiştir. Tülay Germen'in seslendirdiği geleneksel bir türkü olan "Burçak Tarlası" ${ }^{1}$ ise sözü ve müziği yerli olmasından dolayı o dönemki popüler müzik piyasası için adeta bir devrim niteliği taşımaktadır. Zamanla plak endüstrisinin gelişmesi ve gazinoların yaygınlaşması ile birlikte özellikle kent yaşamında giderek hareketlenen müzik endüstrisi, bugün Türk popüler müzik tarihinde önemli bir başlangıç olarak gösterilen Erol Büyükburç ile yeni bir ivme kazanmıştır. "Büyükburç aranjman modası ile fazla ileri gidemeyeceğinin görür ve modalara karşı durup türküleri modernleştirmeyi cesurca deneyen ilk isim olur... ilk kez halk müziğinin örneklerini batının sazlarılla bizim sazları birleştirerek yorumlar ve geniş kitlelere aktarır" (Cambazoğlu, 2009: 23). Arayış yılları olarak ülkede oldukça tartışılan 1960'lı yıllar, geleneksel halk müzikçileri ile halk ezgileri ve sözlerini kullanarak Batı tarzı çalgılarla müzik yapan genç gruplar arasında bir "yozlaşma" (?) meselesine dönüşmüştür. Türkiye'de aranjman müziğin öncü isimleri arasında en önemlileri şüphesiz Febri Ebcioğlu ve Sezen Cumhur Önal'dır. "Müziğimizde aranjman kavramı da bu isimlerle yerleşmiştir" (Erkal, 2013: 76). Aranjman sonrası dönemde oluşan Anadolu Pop kavramı ise ilk kez dönemin önemli gruplarından Moğollar tarafından kullanılmıştır (Cambazoğlu, 2009; Bengi, 2017: 24). iki dönem ve kavram arasında bir nevi, eski ve yeni arasındaki müzikal dönüşümün sınırları ve içeriği de belirlenmiştir.

\section{Aranjmana Karşı Halk (Folk) Müzikleri}

1960'lı yıllar esasında Türk popu için arayış yılları olarak ifade edilmektedir. Erol Büyükburç ile başlayan ve Ajda Pekkan gibi isimlerle kentli ve Avrupai melodiler üreten şarkıcıların aranjman müzikleri, Moğollar, Cem Karaca, Barış Manço gibi önemli isimlerle birlikte daha Anadolu kokan ezgiler yaratmaya başlamışlardır. Anadolu pop/rock denilen kavram da aslında Batı odaklı üretilen müziklere tepki olarak çıktığı söylenebilir (Stokes, 2012: 171). Bununla birlikte 1965 yılında Hürriyet gazetesinin düzenlediği "Altın Mikrofon" yarışması, 1967 yılında Milliyet Gazetesi'nin "Liseler Arası Hafif Batı Müziği Ses Yarışması" (1967) ve Robert Kolejinin düzenlediği "Boğaziçi Müzik Festivali" (1963-64-65) ile başlayan Türk müziğine dönük kıvılcımlar, aranjman müziklerin yavaş yavaş tedavülden kalkmaya başladığı bir süreci beraberinde getirmektedir. Hürriyet gazetesinin tertiplediği Altın Mikrofon (1965-1968) yarışması gazete yönetimi tarafından şöyle belirtilmiştir: "Altın Mikrofon Armağanı Yarışması, Batı müziğinin zengin teknik ve şekillerinden faydalanılarak, yine Batı müziği aletleri çalınmak suretiyle Türk musikisine yeni bir yön vermek için hazırlanmışırı" (Bengi, 2017: 17). Şerif Muhittin Targan, Safiye Ayla, Zeki Müren ve Sezen Cumhur Önal gibi dönemin usta müzisyenlerinin 4 yıl boyunca jüri üyeliği yaptığı Altın Mikrofon ödülleri, genç orkestralar tarafından halk ezgilerinin modernize edilmesi ve yerli müziklerle şarkılar bestelenmesi gibi küçük çaplı

\footnotetext{
${ }^{1}$ Bu parça aynı zamanda Yugoslavya'da Balkan ülkelerinin katıldığı “10. Balkan Melodileri” festivalinde Türkiye'ye birincilik ödülü getirmiştir.
} 
hareketleri daha derli toplu hale getirerek ileride adına "Anadolu Pop" denilecek olan akıma da öncülük etmiştir. Erol Büyükburç bu anlamda ilk denemeleri yapan şarkıcı olarak anılmaktadır. "Erol Büyükburç'un "modern türküleri”nin ilgiyle karşılandığı gören Hürriyet gazetesi, Türkçe sözlü hafif müziğin gelişmesi için ülke çapında Altın Mikrofon yarışması düzenler" (Cambazoğlu, 2009: 23). Anadolu'nun çeşitli yerlerinde düzenlenen ve halktan jürilerin yer aldığı yarışmalarda batılı sazlarla milli bir pop müzik akımının önü açılmış olur ve halk türküleri yeniden modernize edilerek düzenlenmeye ve seslendirilmeye çalışılır. Hürriyet gazetesinin başlattığı bu yarışma Anadolu Pop'un ilk kıpırdanmalarını da beraberinde getirir (Cambazoğlu, 2009: 22-23). Tülay Germen'in "Burçak Tarlası" ile başlayan ve "Mavi Işıılar" adlı grup ve Erol Büyükburç'un öncü çabaları ile devam eden yerli pop akımı, Türkiye'de halk müziğinden beslenen popüler müziğin önemli isimleri olarak da tarihe geçer. 1956 yılında "Little Lucy" adlı parça ile Amerika'yı kasıp kavuran rock'ın roll tarzının da Türkiye'de filizlenmesini sağlayan isim yine Erol Büyükburç olmuştur (Erkal, 2013: 77).

1960'lı yılların sonu ve 1970'li yilların hemen başında Türk popüler müziğine/Anadolu popa yön verecek ve can suyu olacak olan Barış Manço ise, 60 ve 70 yılları arası müzik çalışmalarını Belçika ve Fransa'da sürdürmüştür. Dönem dönem kısa aralıklarla ülkeye gelen Manço, yurt dışında edindiği tecrübelerle birlikte 1970 yılı ve sonrası Türk Popüler müziğine damga vuracak olan "Dağlar Dağlar" adlı parça ile Türkiye'de popüler müzik kültürünün ve halk ezgilerinin en önemli isimleri arasına girerek müzik adına yönünü tamamen Türkiye'ye, Anadolu'ya çevirir. 1970' ve sonraki yıllar ise hem Türk popu için hem de Barış Manço için en önemli müzik çalışmalarının yapııldığı yıllar olur.

\section{“Batıdan Gidip Doğu'yu Bulmak"; Barış Manço}

1943 yılında Üsküdar'da dünyaya gelen Barış Manço, 20. yüzyılın ikinci yarısından sonraki süreçte Türk müziğine gerek sanatçı kişiliği gerekse şarkıları ile damga vurmuş sayılı insanlardan biridir. 1999 yılına kadar sürdürdüğü yaşamında 200'e yakın bestesi olan, Türkiye'yi dünyaya, dünyayı da Türkiye'ye tanıtan bir müzik adamı... 1950'li yılların sonunda başladığı profesyonel müzik yaşamı boyunca hem Türkiye'de hem de dünyanın çeşitli bölgelerinde adından söz ettirmeyi başaran Manço, Türkiye'nin popüler müzikte üretiminin, yaratıcılı̆ıın ve özgün çalışmaların azaldığı bir dönemde genelde Türk müziği özelde ise Türk popüler müziği adına can suyu olmuştur. O kendi ifadesi ile "bu dünyaya şarkıcı olarak gelmemiş", (Erdoğan, 2018: 63-76) insanlara bir şeyler anlatmak, kaybettiği değerleri yeniden hatırlatmak üretmiş bir sanatçıdır.

Ses dergisinin Zeki Müren'le yaptığı röportajda, Zeki Müren'in Anadolu pop ile ilgili tespiti Barış Manço'nun söz konusu müzik akımı adına ne derece önemli olduğunun da altını çizmektedir: "Folk akımı müzik dünyamıza dinamizm, birçok genç kabiliyet ve en önemlisi Barış Manço ve Selda (Bağcan) gibi iki değer getirmiştir. Ne götürdüğüne gelince, her yeni akımın bir yığın aksaklıkları olur. Yıkııı tenkitlerle onları yıpratmak, ortadan kaldırmak bence yersizdir" (Cambazoğlu, 2009: 33). 
Parçalarını geleneğin mirası üzerine modern biçimlerle kurduğunu ifade eden sanatçı, eserleri ve müzik anlayışının nasıl şekillendiğini ise Zeki Müren ve kendisi arasındaki ilişkiyle birlikte şöyle aktarmaktadır: "Zeki Müren, halkı, folklorumuzu ve müzik olayını biliyordu. Bunu ben de biliyorum. Buraya üç ay usul dersi alarak gelmedim. Bugün yaptığımız müziklerde Hititlerden Erzurum Baş Barı́na kadar Anadolu müzik evriminin titiz bir araştırması vardır. Bugün yaptığımız müzikte Nasrettin Hoca'nın mizahı, Hacı Bektaş Veli'nin felsefesi, Dede Korkut'un töre, gelenek ve dinamizminin etkilerini görebiliyorsanız bu da bir rastlantı değildir" (Tunca, 2014: 325).

Türkiye'nin 1960 sonrası süreçte arayış yılları olarak düşünülen pop müzik tarihinde Barış Manço, müzik piyasasına yeni girmiş ve ilk plak/albüm denemelerine Avrupa'da (Fransa ve Belçika'da) başlamıştır. ilk albümünü Fransa'da yapan sanatçı bir süre sonra Belçika'ya yerleşmeye karar vermiş ve çalışmalarına (aynı zamanda okul hayatına) burada devam etmiştir. Bu süre zarfında Türkiye'ye kısa aralıklarla gelen sanatçı, pek çok önemli isimle birlikte çalışma ve konser verme imkânı da bulmuştur. Ancak o hiçbir zaman yaşadığı kültürü ve tarihi unutmamış, 1960-1970 yılları arasında Türkiye'de çıkardığı albümlerde/plaklarda hem kendi bestelerini hem de anonim türküleri modern çalgı teknik ve soundları ile yorumlayabilmiştir. Nitekim Avrupa macerasını bitiren ve yüzünü Anadolu'ya dönen Manço'nun müzik yaşamındaki dönüm noktalarından birini okul ve (eski) grup arkadaşı Ender Enön şöyle anlatmaktadır:

ılk defa Türkiye'den isçi akını başladı. Akın değil de çekingen bir geliş diyelim. Türkler gelmeye başladı. Anadolu'nun en uzak köşesinden gelip Belçika'nın Avrupa'nın göbeğinde çok farklı bir kültüre düşen insanlar... gariban gariban kafelerde oturuyorlar. Biz de dedik ki biz bir kafede müzik yapalım. Şenlensin burası falan. Kafe sahibi de kabul etti. Hem bize harçlık olur. Biz başladık orda çalmaya ama çaldığımız müzik Elves Presley'ler rock'ın roll'lar... o zamanın Batı müzikleri. Kimse dinlemiyor bizi. Pişti oynuyor çay içiyorlar ama hiç dinleyen yok bizi. Biz paramızı alıp gidiyoruz ama tatmin olmuyoruz. $O$ ara içlerinden birisi dedi ki; "ağabeyler bana müsaade edin memleketten bir türkü çağırayım” dedi. Tamam dedik. Sesi de güzeldi hatırlıyorum Nurettin Topçu. (acaba duyar mı buradan?) sonra samimi olduk o işçilerin hepsi ile. “Kağızman'a ısmarladım nargile nargile” yanık yanık bir söyledi bunu yer yerinden inledi. Ne pişti oynayan kaldı ne çay içen kaldı. Biz kıskandık imrendik. Biz burada neler yapıyoruz. Aletler gitarlar falan, yok... o götürdü işi. Onun üzerine Barış mesajı aldı. Başladık bunları prova etmeye. Bir yerde bizim müziğimizde Anadolu müziğiydi. "Neden Batı müziğini oradakilere bizim insanımıza çalmaya çalışıyoruz? Sevilen neyse ruh ordadır” dedi Barış. Ve bu çalgılarla Anadolu müziği yapmaya karar verildi o gün (Erdoğan, 2018: 64-73).

Bu olay sonrası Barış Manço yönünü tamamen doğuya çevirmiş ve 1969 yılında Sayan Plak'tan çıkardığı tek şarkılık albümde “Kağızman'a Ismarladım Nar

http://dergipark.gov.tr/aicusbed 5/1 Nisan / April 2019 
Gele" adlı türküyü okumuştur. Nitekim yukarıda aktarılan anekdot onun 1960 sonrası Anadolu müziğine yönelişinin de adeta bir özetidir. Sırası ile Manço, 1970'de "Dağlar Dağlar”, 197ı'de ise “i̧şte Hendek işste Deve” ve aynı yıl "Binboğa'nın Kızı" adlı plakları çıkarmıştır. Söz konusu bu üç parça Barış Manço'nun Türk kültür tarihinden seçtiği ve bir anlamda yeniden kurguladığı pek çok halk kültürü unsurunu içermesi bakımından için önemlidir.

Barış Manço halkın içerisinde tecrübe ettiği, dinlediği olayları anlatmak istediği konuyu muazzam bir hayal gücü ile birleştirmektedir. Barış Manço'nun çağdaşı sayılan ve 20. yy. âşık edebiyatımızın önemli isimlerinden Mahsuni Şerif, "ozanı", "sanatçıyı" tarif ederken hayal ve benzetme dünyasının bir sanatçı için ne derece önemli olduğunu şu cümlelerle ifade etmektedir; "Ozanlık sanatı imajlar sanatıdır. Bir ima sanatıdır. Bir de cinaslar sanatıdır." Barış Manço’nun eserlerine bütüncül bir perspektiften bakılacak olursa sözü geçen imalar, cinaslar ve imajlar sıklıkla yer bulmaktadır. Ayşe Egesoy'un 1989 yılında TRT ekranlarında Barış Manço ile bir röportajında Barış Manço'ya şarkı sözlerini nasıl yazdığını ve bestelediğini sorusu üzerine Manço şu yanıtı veriyor:

Olayların hepsi bizim halkımızda toplumumuzda var. Tarihimizde, geçmişimizde, kültürümüzde... inamılmaz zengin bir Türk kültürü var. Bunu söylemem abes herkes biliyor. Çok canlı yaşayan bir halk kültürümüz var bizim. Ben oradan elimi daldırıp daldırıp çıkartıyorum. Benim kafam sürekli bunlarla dolu zaten. Bir gün "Sarı Çizmeli Mehmet Ağa” oluyor, bir gün "Halil Ibrahim Sofrası” oluyor...(Erdoğan, 2018: 65-73).

Tarihini, kültürünü ve geleneklerini tanıyarak eserlerinde işleyen Manço, çocukluk yıllarında şekillenen düşünce dünyasını ise şöyle aktarmaktadır:

Çoğu çocuk böyle tabanca, top, tüfek, kovboyculuk falan oynarken ben bunları bilmezdim. Biz hep böyle kendi kafamıza göre karagöz perdeleri yapardık, küçük orta oyunları yapardık. O zamanla Ismail Dümbüllü, Halide Pişkin vardı (ikisi de rahmetli oldu çok büyük radyo sanatçıları idi). Onları dinleyerek büyürdük. Işste istanbul'un Fethi'ni yapardık oyun olarak, ben hep Ulubatlı Hasan olurdum her seferinde. Yani sonuçta bugün ortaya çıkan benim kişiliğim zannediyorum o yıllarda başlayan filizlenmeler (Erdoğan, 2018: 6573).

Türk kültür tarihini ve karakterlerini yakından takip eden, yaptığı eserler ve düşünceleri ile Türkiye'de popüler müziğin yerel dinamiklerden beslenen bir çizgide oluşmasında önemli pay sahibi olan Manço, besteleri, müzikleri ve eserlerinde yerel ve evrensel temalar ile geçmişten aldığı mirası çağının müzik anlayışına uyarlayabilmiştir.

1960'lı yıllar boyunca Türkiye'yi kasıp kavuran Aranjman modasına anonim türkülerle, karşı duran Manço, Akşam gazetesine verdiği demeçte şunları ifade

\footnotetext{
2 Ülke TV, Gönül Dağı Programutube.com/watch?v=JKyYZq9flt4" https://www.youtube.com/watch?v=JKyYZq9flt4.
} 
etmiştir: "müzik dünyamızda ilgi çekici bir gelişme var. Bizle uzaktan yakından hiçbir ilgisi olmayan 20-30 yıllık 2. Harp sonrası Avrupa'da ün yapmış şarkıları ipe sapa gelmez sözlerle ortaya süren bilinçsiz bir grubun yanı sıra, bugüne kadar alaturka alafranga diye ikiye ayrılmış olan Çağdaş Türk Müziğinin iki yönden kıvrılarak uç uca geldiğini anlayanlar da var. Aynı Macellan gibi. Batıdan gidip doğuyu bularak... Doğu o kadar derin ki..." (Bengi, 2017: 96).

\section{0-1970'li Yıllarda Barış Manço Eserleri}

XX. Yüzyılın ikinci yarısından itibaren Türk müziği adına yapılan çalışmaların daraldığı ve gelişen teknolojik dünyaya uyum sağlayacak yeni gelişmelerin sınırlı olduğu Türkiye'de aranjman müzik ile başlayan süreçte yerel motifleri kendi müziğine aktarmış olan Manço, bugün adına Anadolu pop/rock denilen türün gelişmesinde de en büyük pay sahibi sanatçılardan biri olmuştur. 1962 yılında yayınladı̆̆ı plakta bir Anadolu türküsünü dönemin Twist modasına göre uyarlayan Manço, Harmoniler adlı grubu ile "Twist in Usa-Çıt Çıt Twist \& Dream Girl” (1962) adlı üç 45'lik plakla müzik yaşamına adım atmıştır. "Çıt Çıt Çedene" adlı çalışmayı takiben “Urfa'nın Etrafı \& Kızılcıklar Oldu Mu?’’ adlı çalışması Manço'nun yüzünü tamamen Anadolu'ya döneceğinin de sinyallerini vermiştir. 1970 yılında çıkardığı “Dağlar Dağlar” adlı albümü ise Barış Manço'nun 1970 sonrası Türk müziğinin gideceği yönü belirlemiş ve Türk müziğini folklorik temalarla süsleyerek, dönemin modern müzik teknolojisini de yakından takip etmiştir.

"Dağlar Dağlar" (1970) plağı Türk müziğinin makamsal karakterini yansıtmasının ve sözel yapısının halk müziğinin temaları ile örtüşmesi bakımından önemlidir. Bunun yanı sıra eserde kullanılan klasik kemençe ve gitar çalgıları, Barış Manço müziğinin doğu-batı çalgı çeşitliliğini taşıması bakımından da dikkat çekicidir. Halk kültüründe dağ motifi âşık ile maşuk arasındaki engeli anlatan bir metafordur. Dolayısıyla dağlar sevgiliye ulaşmadaki en önemli engel olarak tasvir edilir. Nitekim bu motifin en bilinen örneği Doğu edebiyatında "Leyla ile Mecnun" hikâyesinde anlatılmaktadır. Barış Manço'nun eserinde kullandığı dağ motifi de bu paralelde işlenmiştir: "kurban olam yol ver geçem, sevdiğimi son bir olsun yakından görem."

Barış Manço'nun 1970'liyıllara damgasını vuran diğer eseri ise “ịşte Hendek İşte Deve" (197ı) adlı parçadır. Bu parça aynı zamanda Barış Manço'nun o dönemin ünlü grubu olan Moğollar ile birleşmesinden sonra çıkarttı̆̆ı ilk plaktır. Grubun adı "MançoMongol" olarak belirlenmiş ancak sadece iki adet kırkbeşlik kaydettikten sonra grup dağılmıştır. (Bu parçalar; Işste hendek işte deve, Binboğanın kızı, Kâtip arzu halım). Eser "Kuyu başına vardım Zeynebi görem diye nasıl haberin almısssa dayı emmi hep orda, dediler ne ararsın kızı almak mı istersin sana bir çift sözümüz var hele buysa niyetin...” sözleri ile başlıyor. Anadolu'da kız alma geleneğine gönderme yaparak bu geleneğin nasıl olduğuna dair bir hikâye anlatan Manço eserin

\footnotetext{
3 Barış Manço'nun kurduğu Harmoniler adlı grup 1962 yılında bu parçaları kaydetmiş ancak 1968'de yayımlanabilmiştir. 1963 yılında ise Barış Manço Belçika'ya öğrenim görmek üzere gider ve burada Fransızca ve İngilizce sözlü çeşitli plaklar doldurur.
}

http://dergipark.gov.tr/aicusbed 5/1 Nisan / April 2019 
sonunda; "zordur almak bizden kızı" diyerek kızı alabilmek için aslolanın para değil; görgü, mertlik ve güzel ahlak olduğunu anlatmaktadır.

1971 yılına damga vuran bir diğer önemli Barış Manço eseri ise "Binboğa'nın Kızı" adlı parçadır. Bu eser Yaşar Kemal'in ${ }^{4}$ (197ı) yılında yazdığı "Binboğalar Efsanesi" adlı bir destansı romandan hikâyeyi anlatmakta ve hikâyenin geçtiği bölgede (Adana) yaşamış olan Yörük Türkü Karacaoğlan'ın aşağıdaki dizelerine gönderme yapmaktadır.

$$
\begin{gathered}
\text { Kozan Dağından neslimiz } \\
\text { Arı Türkmen'dir aslımız } \\
\text { Varsak'tır durak yerimiz } \\
\text { Gurbette yar eğler bizi } \\
\text {.. } \\
\text { Vatanımız Adana, Maraş } \\
\text { Çukurova il'imiz var. } \\
\text { Yaylamız Bulgar Dağıdır. } \\
\text { Binboğa'dır benim il'im. }
\end{gathered}
$$

Burada bahsi geçen Kozan Yaylası, bugün Adana'nın sınırları içerisinde olan ve Türkmen aşiretlerinin o dönem göç ederek yerleştikleri yayla bölgesidir. Karacaoğlan'ın da buralı olduğu burada yaşadığı sanılmaktadır. Barış Manço eserinde Karacaoğlan'ın eserine gönderme yapmaktadır:

Kozan yaylasından geldim Barıştır adım,

Bugün varsak yarın yoğuz doğrudur sözüm, Bir gün elbet biter bâdem çağırır Tanrım,

Artık mahşer gününde ararım seni

Aynı yıl Kurtalan Express ile yollarını birleştiren sanatçı, bu dönemle birlikte kendi söz ve bestelerini oluşturmuş ve 1970 sonrasında Türk pop müziğinin adeta kaderini de belirlemiştir. "Kâtip Arzu Halim" (1971), "Küheylan" (1973), "Hey Koca Topçu/Genç Osman" (1973), "Estergon Kalesi"(1974), "Kayaların Oğlu” (1975,) onun müziğe nasıl yerel bir kimlik ve şuur kattığını gösteren en iyi eserlerinden sadece birkaçıdır. Özellikle "Hey Koca Topçu/Genç Osman" (1973) ve “Estergon Kalesi"(1974) adlı eserleri tarihin satır aralarında kalmış olayları anlatması ve mehter müziğinin güçlü ritimlerinin ön planda olduğu müzikal karakterleri yansıtması bakımından oldukça önemli çalışmalardır. Zira 1930-1940'lı yıllardan sonra yönünü tamamen batıya çeviren Türkiye'de Barış Manço, geleneksel kültürle popüler kültürü başarıyla harmanlayabilmiştir. Barış Manço'yu çağdaşlarından ayıran en büyük özelliği ise eserlerinin çoğunu kendi yazmış olması ve türkü formunda oluşturduğu hikâye türündeki eserlerine tarihi derinlik katabilmesidir. Nitekim 1971 yılında Pir Sultan Abdal'dan "Kâtip Arzu Halim" adlı türkü bunun en güzel örneğidir. Eserin ezgi ve söz yapısına sadık kalan Barış Manço ara nağmede özgün bir denemede

\footnotetext{
${ }^{4}$ Ayrıca bakınız; Yaşar Kemal, (1988). Binboğalar Efsanesi, istanbul; Yapı Kredi Yayınları.

${ }^{5}$ Ayrıca bakınız; Cahit Öztelli (2005) Karacaoğlan, “Bütün Şiirleri”, İstanbul: Özgür Yayınları.
} 
bulunarak, Türk kültür tarihinin kritik dönemlerini hikâye türünde anlatmıştır. Eserde gitar ve klavye gibi batı çok sesli çalgılarının yanı sıra kabak kemane gibi klasik Türk müziği sazlarını birlikte kullanan Manço, doğu ve batı müzik kültürlerini harmanlamıştır. Eserin ara nağmesinde Barış Manço 1970'li yılların sağ-sol çatışmasından kaynaklı kaos ortamına gönderme yaparak şu dizelere yer vermektedir: YIl 1535 Pir Sultan Abdal bunu böyle söylemiş, söylemiş ya bunun bir de evveli var. Kâtip al kalemi bir de benden yaz. Boy boy gelmişler şu dağların ötesinden. Burası bize otağı olsun, yurt olsun demişler. Boy boy yerleşmiş boy boy girmişler. Her sabah gün doğusundan 2 mizrap boyu yükselen güneş bir gün kendini göstermeyince kara kara bulutlar dolaşmış bu cennet vatan üzerinde. Küçük büyüğü saymaz olmuş. Kardeş kardeşe küsmüş. En acısı bacılarımızın yüzüne bakamaz olmuşuz. 1535163517351835193535 de benden koyun kardeşlerim. 1970 geldik. Bir uğursuzluk gelmiş ki başımıza sürüp gitmekte. Oysa deli gönül neler ister. Barış bir yavrusu olsun ister adını bile hazırladığ. Oğlansa Ozan kız ise Ceylan. Ceylan buz gibi pınarların aktığı zümrüt ovalarda taştan taşa seksin. Ozan Ardahan'dan Kırkpınarı dolaşsın. Anlatsın Karacaoğlan', Pir Sultan Abdal', Köroğlu'nu davullar yine vurulsun. Güneş yine iki mizrap boyu yükselsin gün doğusundan. Bitsin artık bu küskünlük kardeşlerim. Uzatalım ellerimizi. Yarın tarih önünde hesap verirken, yavrularımı bizi kınamasınlar. ${ }^{6}$

Bu eser, Barış Manço'nun 1970 ve sonrası süreçte Türkiye'nin popüler müzik alanında beslenmesi gereken tek kaynağın yine kendi kültürü olması gerektiğinin altını çizmesi açısından önemli bir parçadır. Barış Manço'nun popüler müzik tarihimizde ve Anadolu pop olarak kavramsallaşan dönemde yönünü Anadolu'ya çevirmesi, onun müziğini anlayabilmek ve bugün hala hit olan eserlerini hangi tecrübeler sonrası oluşturduğunu anlayabilmek adına da önemlidir. 1960 yılının aranjman müzik akımı yerini $70^{\prime} l i$ yılların daha milliyetçi ve halkçı söylemleri ile birlikte yeniden şekillenirken Anadolu pop/rock akımı da gelişmiştir.

Barış Manço'nun genel müzik kimliğini anlatan eserleri 1970 yılında olgunlaşmış ve 1980 sonrası süreçte de devam etmiştir. Nitekim "eserlerinde Türk töresini (Halil ibrahim Sofrası), Anadolulu insan tipini (Sarı Çizmeli Mehmet Ağa) ve kadim Türk tarihinden olayları (Estergon Kalesi, Kayaların Oğlu, Küheylan, Genç Osman) konu etmesi bakımından Barış Manço, çağdaşlarından ayrılarak, müziğine milli bir şuur katmıştır. Orta Asya'dan Anadolu'ya kadar yayılan ozan-baksı geleneğini popüler müzik alanına ustaca taşıyabilen Manço, eserlerinde "Barış der ki...", diyerek bin yıllık halk ozanlığına da atıfta bulunmaktadır" (Erdoğan, 2018: 65). Türk popüler müziğinde bugün bile geçerliliğini ve popülerliğini koruyan parçalar olarak 1970'li Barış Manço'nun yukarıda zikredilen albümleri/eserleri o döneme damga vurmuştur. Hem albüm kayıtları, hem de dönemin müzik türleri göz önüne alındığında progressive tarzın en iyi örnekleri olarak bu parçalar düşünülmektedir.

\footnotetext{
${ }^{6}$ Parçanın söz ve müzikleri için ayrıca bkz., https://www.youtube.com/watch?v=1l9y]_Bj6PU
} 
1975 yılındaki "Kayaların Oğlı" adlı albüm", Türkiye'de bu türün ilk ve en iyi örnekleri arasında gösterilmektedir. Barış Manço'nun Türkiye'nin 2023 Cumhuriyet'in 100. Yll vizyonuna göndermede bulunduğu eserde albüm olarak dönemin başarıı müzik teknolojileri kullanılmıştır.

Sonuç

1960'da aranjman modası ile başlayan, 1970'lerde ise giderek Anadolu motifleri üzerine kurgulanan Türk popu, dönemin kültürel ve siyasi atmosferine paralel bir biçimde şekillenmiştir. Söz konusu süreçte bugün de adından söz ettiren pek çok sarkıcı ve grup ise, 1960 'lı yıllarda Hürriyet gazetesinin tertiplediği "Altın Mikrofon", Milliyet gazetesinin "Liseler Arası Hafif Batı Müziği Ses Yarışması" ve Robert Kolejinin düzenlediği "Boğaziçi Müzik Festivali" sayesinde ivme kazanmıştır. Barış Manço ise $1960^{\prime} \mathbf{l}_{\text {ı }}$ ylların aranjman müzik akımına adeta bir tepki olarak Anadolu'nun kendi melodileri ve bestelerinden faydalanmış, zamanla kendi müzikal kimliğini oluşturmuş ve 1970 sonrasında Türk popüler müziğine iz bırakabilmiştir. Barış Manço Türkiye'ye müzikal açıdan bıraktıklarından çok daha azı sayılacak nitelikte hakkında çalışma yapılmış olması, onun yaşadığı dönemde olduğu gibi, bugün de tam olarak anlaşılamadığı fikrini doğurmaktadır.

1960'lı yılların aranjman müzikleri ile Türk popüler müziğinin ilerleyemeyeceğini belirten Barış Manço Anadolu ezgilerinden ve ozanlık geleneğinin sözel unsurlarından faydalanarak müzik yaşamını şekillendirmiştir. "Barış Der ki..." diyerek eserlerini şekillendiren Manço, yüzlerce yıllık ozanlık geleneğini tekrar popüler müzik alanına taşıyabilmiştir. Şarkılarında günü kurtaracak basitlikte değil, yıllar sonra da adından söz ettirecek işlere imza atmaya gayret etmiş olması Manço'yu özellikle 1970'li yılların başından itibaren ön plana çıkarmıştır. 1970'te çıkardığı "Dağlar Dağlar" adlı plağı, 1973 yılında ki “2023" adlı deneysel albümü ve Moğollar Grubu ile yaptığı "ịste Hendek işste Deve" (1971) adlı parçaları Barış Manço'nun ve Türk popüler müziğinin de geleneksel halk müziği ile yeniden modern bir çizgide buluşmasını sağlamıştır. Söz konusu parçalar Türk popüler müziğinin de en iyi çalışmaları olarak tarihe geçmiştir. Eserlerinde Dede Korkut'tan, Mevlana'dan, Hacı Bektaş Veli'den, Pir Sultan'dan dolayısı ile Türk kültür dünyasından beslenen Manço, 1960-1980 arası süreçte yaptı̆̆̆ eserleri ile gündelik ilişkilere ve eğlencelere dayalı olarak üretilen müziklerin ötesinde, kendi söz ve bestelerini yaparak geleneksel unsurlardan ve tarihi karakterlerden yola çıkmış, bu anlamda da Türk popüler müziği adına önemli çalışmalara imza atarak müziğini doğu ve batı ikilemine sıkışmadan oluşturabilmiştir. Barış Manço kendi yazdığı güçlü sözel yapı ve konularla, geleneksel halk müziğine yeni bir dinamizm getirirken, popüler müzik alanında da Türkiye'ye özgün çalışmalar kazandırabilmiştir. Nitekim Batıdan edindiği tecrübeler ve müzikal birikim, onun Türk popüler müziğinde önemli çalışmalara imza atmasını sağlamıştır.

\footnotetext{
${ }^{7}$ Ayrıntılı bir çalışma için bakınız; Göktürk Erdoğan, “Orta Asya'dan Anadolu'ya Uzanan Bir Köprü: Barış Manço ve Türk Kültür Tarihi”, l. Uluslararası Develi-Aşsı Seyrani ve Türk Kültürü Kongresi, Kayseri/Develi, 04-05-06 Ekim 2018, s. 64-73.
}

http://dergipark.gov.tr/aicusbed 5/1 Nisan / April 2019 
Neticede Barış Manço, kendi söz ve müzikleri ile döneme damgasını vurmuş ve eserlerini Türk kültüründen aldığı birikimle oluşturarak çalışmalarına tarihsel bir anlam ve derinlik katarak XIX. yüzyılın ikinci yarısından itibaren Türk popüler müziğine adını yazdırabilmiştir.

\section{Kaynakça}

Bengi D., (2017), 60’łı Yıllarda Türkiye: Sazlı Cazlı Sözlük, İstanbul: YKY.

Cambazoğlu, C. (2009), Kentin Türküsü: Anadolu Pop-Rock, isstanbul: Pan Yayıncllı.

Erdoğan G., (2018), “Orta Asya'dan Anadolu'ya Uzanan Bir Köprü: Barış Manço ve Türk Kültür Tarihi”, I. Uluslararası Develi-Aşsı Seyrani ve Türk Kültürü Kongresi, Kayseri/Develi, 04-05-06 Ekim 2018.

Erdoğan G., (2018), Müzikolojide Kültürel Yaklaşımlar ve Müzik Kültürü Üzerine Eskizler, Ankara: Gece Kitaplı̆ı̆.

Erkal, G., E., (2013), Türkiye Rock Tarihi ı, İstanbul: Esen Kitap.

Kahyaoğlu, O., (2010), Cazdan Popa müzikli Yolculuk, İstanbul: Everest Yayınları.

Kemal, Y. (1988). Binboğalar Efsanesi, İstanbul; Yapı Kredi Yayınları.

Öztelli, C. (2005) Karacaoğlan, Bütün Şiirleri, i̇stanbul: Özgür Yayınları.

Stokes M., (2012), Aşk Cumhuriyeti, Türk Popüler Müziğinde Kültürel Mahrem, (Çeviri: Hira Doğrul), i̇stanbul: Koç Üniversitesi Yayınları.

Tunca H., (2014), Seksenler, i̇stanbul: Esen Kitap. 